\title{
Floor Maintenance as a Possible Cultural Behavioural Status? Preliminary Interpretations of Floor Formation Processes from Medieval Brno, Czech Republic
}

\author{
Lenka Lisáa $^{a^{*}}$ Pavel Staněk ${ }^{\mathrm{b}}$, Antonín Zůbek ${ }^{\mathrm{b}}$, Ladislav Nejman ${ }^{\mathrm{c}}$ \\ anstitute of Geology, Czech Academy of Sciences, Rozvojová 269, Prague 6, 165 00, Czech Republic \\ ${ }^{b}$ Archaia, Bezručova 15/78, 60200 Brno, Czech Republic \\ 'School of Historical and Philosophical Inquiry, University of Sydney, Sydney, Australia
}

\section{ARTICLE INFO}

\section{Article history:}

Received: $20^{\text {th }}$ January 2020

Accepted: $22^{\text {nd }}$ April 2020

DOI: http://dx.doi.org/10.24916/iansa.2020.1.5

\section{Key words:}

micromorphology in archaeological context

living space

timber and earth architecture

masonry burgher architecture

domestic floors

\begin{abstract}
$A B S T R A C T$
The way people used different types of buildings and how they used their living space in the past is often imprinted into the floors of buildings. The term floor is quite complex and to understand it, more than macroscopic observations are needed. One useful method is the application of soil micromorphology in an archaeological context. The timber and earth architecture of medieval Brno is still not well known. A rescue archaeological excavation of block 601 near Veselá Street revealed a unique situation where above-ground floors dated to the $13^{\text {th }}-14^{\text {th }}$ century had survived while buried under a garbage dump and discarded construction material. Two groups of buildings excavated in superposition within different parts of a single plot revealed that it is possible to track different maintenance practices through time and space. In the first building, the hypothesis of sweeping maintenance practice was proposed. In the younger building situated in the same area, the degradation or the removal of a wooden plank floor could have been the origin of the observed micro-structure. In the third and fourth buildings, the maintenance practices were different again due to a wetter environment. The third (older) building revealed hay and straw covering followed by sweeping while mat coverings were laid on the surfaces and swept in the fourth (younger) building. The information deduced from micromorphological observations has not fully solved the questions about the floors, but it has certainly elucidated possible interpretations of the oldest phases of the town's development.
\end{abstract}

\section{Introduction}

The floor is an inseparable part of medieval buildings. It is usually composed of intentionally or non-intentionally prepared material (the passive layer) and a trampled/dumped or maintained layer during the use of the building (the active layer) (see details in Gé et al., 1993 and Rentzel et al., 2017, summarised in Macphail and Goldberg, 2018; Karkanas and Goldberg, 2019). The internal space of a building may include not only domestic floors but also a byre. The formation of the domestic floor depends on many factors (status of the building or its parts, cultural differences, geological background) and the formation processes of the final product may be quite complex and the detailed history difficult to resolve (Lisá et al., forthcoming). In particular,

*Corresponding author. E-mail: lisa@gli.cas.cz floor deposits can be a source of high-value information. Variations in floor residues are being profitably examined in order to understand uses of space and the nature of activities in a settlement (Courty et al., 1989). There is a number of studies dealing with floors from Neolithic tell deposits or prehistoric sunken houses (Novák et al., 2012; Milek et al., 2012; Parma et al., 2011; Kuna et al., 2012) or experimental studies (Macphail et al., 2004; Banerjea, 2015a; 2015b; Lisá et al., forthcoming), but case studies dealing with medieval floor deposits are quite rare (see Macphail et al., 2007 and Borderie et al., 2018).

In every case, the floor usually captures the day-to-day life of the building in some way. It is also frequently the most neglected part of ethnographic research. The maintenance processes which form the floor are not always well known and differ locally and over time. Using micromorpology in an archaeological context is one useful method for recognising 
floor formation processes and the types of domestic floors, stabling or byre waste deposits (Stoops et al., 2010; Nicosia and Stoops, 2017; Macphail and Goldberg, 2018; Karkanas and Goldberg, 2019) combined, for example, with archaeobotany (Lisá et al., forthcoming; Borderie et al., 2018), or geochemistry (Milek et al., 2012; Macphail et al., 2004; Lisá et al., forthcoming).

Most of the research regarding medieval floors has been conducted in England (summary in Macphail and Goldberg, 2018). These floors are typified by the presence of: clay floors; lime-mortared and plastered surfaces; rammed chalk, brickearth "clay" slabs; adobe-like brick earth, plastered floors; or plant-tempered, daub floors. They are usually divided into so-called constructed floors typified by their sterile character of very poorly humic soil, and beaten-floor accumulations typified by their massive and compact structure with generally weak, but sometimes welldeveloped, laminae. These are usually composed of sand, silt and fine brickearth, charcoal, burned soil, organic matter, eggshell, mollusc shell, bone and coprolite fragments. The matrix often includes phytoliths, individual ash crystals and ashy concentrations. Microlaminated occupation floor deposits in various later medieval contexts (AD 1400-1539) have also been observed. These deposits, which probably reflect a hospital regime, are composed of laminae 0.5-1.0 mm thick and show regularly alternating compositions of: 1) ash, fine charcoal, cess, burned fragments of bone, eggshell and soil; and 2) humus, brickearth soil and earthworm granules. In some cases, floor coverings were also recorded as a part of the floor sequence (Dragon Hall site, Norwich - see Macphail, 2003 and Shelley, 2005). There are also a number of sites where planked floor accumulations have been suggested, but these have been found below wooden floors, which usually do not survive. Such deposits are suggested, for example, for grubenhäusers (sunken floored house) fills in the Anglo-Saxon village West Stow (Macphail and Goldberg, 2018, p.378), or for Early Slavic grubenhäusers in Roztoky, Czech Republic (Novák et al., 2012); for trampling effects in general, see Rentzel et al., 2011.

The formation of domestic floors related to a non-bricked, medieval town environment in the Czech Republic, and its information value, has never been previously discussed, even at the macroscopic level. The main aim of this paper is to demonstrate the potential for interpreting the sedimentary record of macroscopically-detected floor layers. How exactly has the layer, identified macroscopically as the floor, formed - and what can be revealed about the formation processes of these layers in terms of the use of space and social cultural status of these sites?

\section{Material and methods}

The oldest phase of Brno burgher architecture is represented mainly by timber and earth buildings constructed only from wood and earth. The masonry burgher architecture appears locally in the late phases of the $13^{\text {th }}$ century (Holub et al.,
2005; 2013; 2015, pp.315-323). Most of the building remains have been located in sunken parts, such as timber and earth cellars. These are the most typical record of the non-masonry constructed buildings in medieval Brno. Above-ground floors are extremely rare due to their poor preservation.

One exception has been noted during a rescue archaeological project realized during the construction of the Janáček Cultural Centre (Figure 1). These excavations revealed above-ground building structures with moreor-less-laminated floor deposits. The documented area is located in the NW part of the historical city of Brno. Two sides of the block were originally delimited by town walls. The medieval residential building was oriented towards Veselá Street leading from the Veselá Gate to the Fish Market (today's Dominikánské Square). The block had nine plots (Vičar, 1965), eight of were oriented towards Veselá street. The rescue archaeological excavation partly unearthed just five of these.

The geological background of the study area is composed of alkaline loess deposits situated on calcareous marine clays (Přichystal, 2011). This sedimentary background has a strong influence on the preservation of organic materials from the study strata. During the period from the $13^{\text {th }}$ to $20^{\text {th }}$ century, the ground level has risen approximately 3 metres, which has helped in the preservation of the above-ground floors. Its present-day altitude is therefore 219.6 metres above sea level (asl). The suggested ground level following its growth during the $13-14^{\text {th }}$ centuries is now some 1.5 metres lower than the present-day.

Two sites (that included four buildings) within the excavated area (Figure 1) were chosen for a micromorphology trial in archaeological research and for a comparison of the identified floor layers. The first site includes an older building 1 (sample 1) and a younger building 2 (sample 2). The second site includes an older building (sample 3 ) and the younger one (sample 4). Each of the sites has an older phase dated to the second half of the $13^{\text {th }}$ century and a younger phase dating slightly afterwards into the second half of the $13^{\text {th }}$ century up to the first half of the $14^{\text {th }}$ century. Floors, i.e. the locations chosen for sampling, are composed of massive as well as thin-laminated layers, but the formation processes of these particular layers, and their interpretation, is not possible based only on macroscopic observations.

The sedimentary sections were macroscopically documented and micromorphological samples were taken from the parts that reflected the lamination (that suggested the floor deposits). Finally, four micromorphological samples from four different locations were cut out of the sections and put into plastic Kubiena boxes. Samples were taped in cling film and transported to the laboratory of the Institute of Geology, Czech Academy of Sciences, where they were slowly dried and subsequently impregnated by resin Pollylite 2000 in a vacuum chamber. After six weeks of curing, the samples were thin-sectioned in an $8 \times 5 \mathrm{~cm}$ format. Samples were described according to Stoops (2003). Detailed micromorphological descriptions are included in Table 1. 


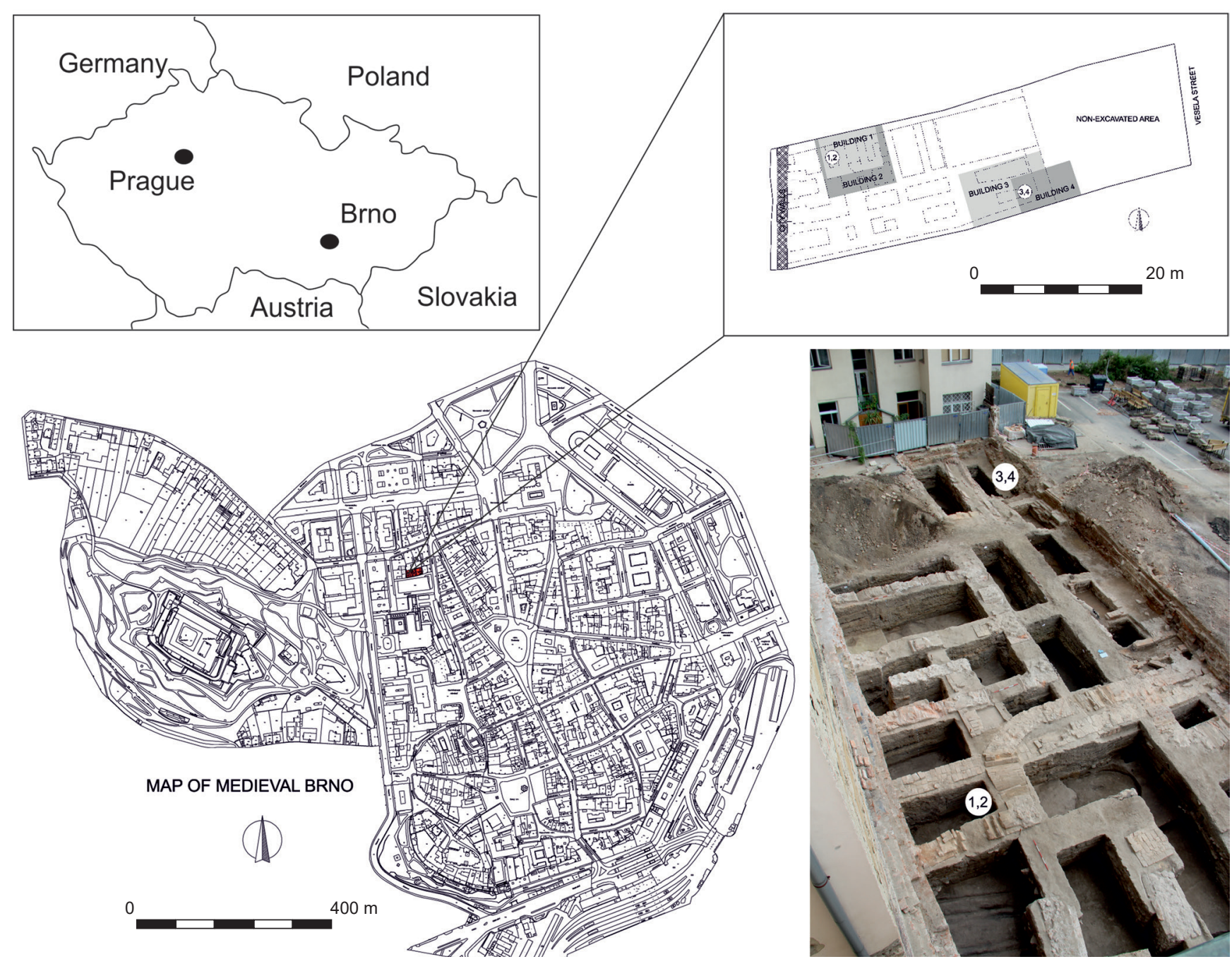

Figure 1. The study area within the block nr. 601 and orientation of the studied buildings within the different plots.

Table 1. Detailed micromorphological description of subfacies detected during observation. The abbreviation in the table: SF - subfacies; CPV - compound packing voids; R - rare; P - present; C - common; OM - organic matter; Q - quartz; Ptg - plagioclase.

\begin{tabular}{|c|c|c|c|c|c|}
\hline Sample & Microstructure & Groundmass & Organic residues & Pedofeatures & Interpretation \\
\hline $\begin{array}{l}1 \\
\mathrm{SF} 1 \\
(1 \mathrm{~cm})\end{array}$ & $\begin{array}{l}\text { Subangular } \\
\text { blocky; pores: } \\
\text { CPV; vughs, } \\
\text { cracks and planes }\end{array}$ & $\begin{array}{l}\mathrm{Q}, \text { Ptg, mica, soil aggregates, } \\
\text { rock fragments; unsorted, } \\
\text { locally oriented, loam; } \\
\mathrm{C} / \mathrm{F}(50 \mu \mathrm{m})=50: 50 . \text { Light } \\
\text { brown aggregates has local } \\
\text { striated } \mathrm{Bf} \text {, dark brown } \\
\text { aggregates has crystalic } \mathrm{Bf}\end{array}$ & $\begin{array}{l}\text { Dark brown and black } \\
\text { dotting - C; partly } \\
\text { decomposed to decomposed } \\
\text { OM - P; charcoal - R; } \\
\text { phytoliths - R }\end{array}$ & $\begin{array}{l}\text { Phosphate } \\
\text { staining - } \\
\text { C; gypsum } \\
\text { crystals }-\mathrm{C} \text {; } \\
\text { passage } \\
\text { features - P }\end{array}$ & $\begin{array}{l}\text { Passive layer - material } \\
\text { representing older } \\
\text { destruction }\end{array}$ \\
\hline $\begin{array}{l}1 \\
\mathrm{SF} 2 \\
(1 \mathrm{~cm})\end{array}$ & $\begin{array}{l}\text { Complex; pores: } \\
\text { vughs, chambers, } \\
\text { cracks, planes }\end{array}$ & $\begin{array}{l}\mathrm{Q}, \text { Ptg, mica, sorted, visible } \\
\text { mineral orientation; loam; } \\
\mathrm{C} / \mathrm{F}(50 \mu \mathrm{m})=50: 50 \text {; brown, } \\
\text { crystalic } \mathrm{Bf}\end{array}$ & $\begin{array}{l}\text { Brown, dark brown doting } \\
-\mathrm{P} \text {, decomposed organic } \\
\text { matter }-\mathrm{P} \text {, charcoal }-\mathrm{P} \text {, } \\
\text { phytoliths }-\mathrm{R} \text {; bones }-\mathrm{R}\end{array}$ & $\begin{array}{l}\text { Gypsum } \\
\text { crystals - P, } \\
\text { phosphate } \\
\text { staining - P }\end{array}$ & $\begin{array}{l}\text { Maintained floor by wet } \\
\text { sweeping }\end{array}$ \\
\hline $\begin{array}{l}1 \\
\text { SF3 } \\
(1 \mathrm{~mm})\end{array}$ & $\begin{array}{l}\text { Platy; pores: } \\
\text { planes }\end{array}$ & $\begin{array}{l}\mathrm{Q}, \text { Ptg, mica; sorted, oriented } \\
\text { articulated phytoliths and } \\
\text { mineral fraction, loam; } \\
\mathrm{C} / \mathrm{F}(50 \mu \mathrm{m})=50: 50 \text {; grey } \\
\text { brown, crystalic } \mathrm{Bf}\end{array}$ & $\begin{array}{l}\text { Articulated phytoliths - } \\
\mathrm{C} \text {; wood fragments - R; } \\
\text { charcoal - C; decomposed } \\
\text { organic matter - C; burned } \\
\text { bone - R }\end{array}$ & Fe staining $-\mathrm{P}$ & $\begin{array}{l}\text { Trampled and } \\
\text { maintained floor - } \\
\text { added straw or mat }\end{array}$ \\
\hline $\begin{array}{l}1 \\
\mathrm{SF} 4 \\
(1 \mathrm{~mm})\end{array}$ & Platy; planes & $\begin{array}{l}\text { Q, Ptg, mica; sorted } \\
\text { homogenous matrix; } \\
\mathrm{C} / \mathrm{F}(50 \mu \mathrm{m})=50: 50 ; \text { brown, } \\
\text { crystalic } \mathrm{Bf}\end{array}$ & $\begin{array}{l}\text { Brown, dark brown doting } \\
-\mathrm{P} \text {, decomposed organic } \\
\text { matter }-\mathrm{R}\end{array}$ & $\begin{array}{l}\text { Phosphate } \\
\text { impregnation - } \\
\text { C; gypsum - R }\end{array}$ & $\begin{array}{l}\text { Intentionally prepared } \\
\text { passive layer highly } \\
\text { influenced by } \\
\text { postdepositional } \\
\text { processes }\end{array}$ \\
\hline
\end{tabular}


Table 1. Detailed micromorphological description of subfacies detected during observation. The abbreviation in the table: SF - subfacies; CPV - compound packing voids; $\mathrm{R}$ - rare; $\mathrm{P}$ - present; $\mathrm{C}$ - common; $\mathrm{OM}$ - organic matter; $\mathrm{Q}$ - quartz; Ptg - plagioclase. (Continuation)

\begin{tabular}{|c|c|c|c|c|c|}
\hline $\begin{array}{l}1 \\
\text { SF5 } \\
(1 \mathrm{~mm})\end{array}$ & $\begin{array}{l}\text { Subangular } \\
\text { blocky; pores: } \\
\text { CPV; vughs, } \\
\text { cracks and planes }\end{array}$ & $\begin{array}{l}\mathrm{Q}, \mathrm{Ptg}, \text { mica, soil aggregates, } \\
\text { rock fragments; unsorted, } \\
\text { locally oriented, loam; } \\
\mathrm{C} / \mathrm{F}(50 \mu \mathrm{m})=50: 50 . \text { Light } \\
\text { brown aggregates has local } \\
\text { striated Bf, dark brown } \\
\text { aggregates has crystalic Bf }\end{array}$ & $\begin{array}{l}\text { Dark brown and black } \\
\text { dotting - C; partly } \\
\text { decomposed to decomposed } \\
\text { OM - P; charcoal - R; } \\
\text { phytoliths - R }\end{array}$ & $\begin{array}{l}\text { passage } \\
\text { features }-\mathrm{P}\end{array}$ & $\begin{array}{l}\text { Passive layer - material } \\
\text { represent older } \\
\text { destruction }\end{array}$ \\
\hline $\begin{array}{l}2 \\
\mathrm{SF} 6 \\
1.5 \mathrm{~cm}\end{array}$ & $\begin{array}{l}\text { Subangular } \\
\text { blocky; pores: } \\
\text { CPV, cracks }\end{array}$ & $\begin{array}{l}\text { Q, Ptg, mica, sorted with } \\
\text { no orientation expect the } \\
\text { occasional presence of straw; } \\
\text { loam, C/F }(50 \mu \mathrm{m})=50: 50 ; \\
\text { light brown, crystalic Bf }\end{array}$ & $\begin{array}{l}\text { Decomposed organic matter } \\
\text { - P; articulated phytoliths } \\
\text { - P; }\end{array}$ & $\begin{array}{l}\text { P staining }-\mathrm{P} ; \\
\mathrm{CaCO} 3 \text { nodules } \\
-\mathrm{P}\end{array}$ & $\begin{array}{l}\text { Passive layer or daub } \\
\text { destruction }\end{array}$ \\
\hline $\begin{array}{l}2 \\
\text { SF7 } \\
(1-1.5 \\
\mathrm{cm})\end{array}$ & $\begin{array}{l}\text { Complex; p: } \\
\text { vughs; cracks; } \\
\text { chambers }\end{array}$ & $\begin{array}{l}\text { Q, Ptg, mica; moderately } \\
\text { sorted loam } \mathrm{C} / \mathrm{F} ; \text { deposited } \\
\text { under the angle; }(50 \mu \mathrm{m})= \\
\text { 50:50; grey brown; crystalic } \\
\text { Bf }\end{array}$ & $\begin{array}{l}\text { Charcoal - C; bones - P; } \\
\text { decomposed OM - P; wood } \\
\text { fragments }-\mathrm{P}\end{array}$ & $\begin{array}{l}\text { Gypsum } \\
\text { crystals }-\mathrm{C} \text {; } \\
\text { P nodules - } \\
\mathrm{C} \text {; silty clay } \\
\text { coating }-\mathrm{C} \text {; }\end{array}$ & $\begin{array}{l}\text { Material accumulated } \\
\text { below the plank floor. } \\
\text { The plank floor was } \\
\text { maintained by wet } \\
\text { sweeping }\end{array}$ \\
\hline $\begin{array}{l}2 \\
\text { SF8 } \\
(1.5-2 \\
\mathrm{cm})\end{array}$ & $\begin{array}{l}\text { Complex; pores: } \\
\text { CPV, cracks }\end{array}$ & $\begin{array}{l}\text { Q, Ptg, increased amount of } \\
\text { mica; moderately sorted sandy } \\
\text { loam, no preferred orientation, } \\
\text { rock fragments; } \mathrm{C} / \mathrm{F}(50 \mu \mathrm{m})= \\
50: 50 \text {; crystalic } \mathrm{Bf} \text {. }\end{array}$ & $\begin{array}{l}\text { Locally organic matter } \\
\text { dotting }-\mathrm{P} \text {; } \mathrm{CaCO} 3 \text { nodules } \\
-\mathrm{P} \text {; upper part }-\mathrm{CaCO} 3 \\
\text { coating }-\mathrm{P}\end{array}$ & $\begin{array}{l}\text { Fe nodule - } \\
\text { R; silty clay } \\
\text { infillings - } \\
\text { P; passage } \\
\text { features - P }\end{array}$ & $\begin{array}{l}\text { Passive layer } \\
\text { composed of alluvium, } \\
\text { partly influenced } \\
\text { by postdepositional } \\
\text { processes. }\end{array}$ \\
\hline $\begin{array}{l}3 \\
\text { SF9 } \\
(2 \mathrm{~cm})\end{array}$ & $\begin{array}{l}\text { Vughy; pores: } \\
\text { vughs; cracks; } \\
\text { chambers }\end{array}$ & $\begin{array}{l}\mathrm{Q}, \text { Ptg, mica, well sorted, } \\
\text { no preferred mineral } \\
\text { orientation;, sorted loam; } \\
\mathrm{C} / \mathrm{F}(50 \mu \mathrm{m})=50: 50 ; \text { light } \\
\text { to grey matrix with brown } \\
\text { crotovinas, crystallic Bf }\end{array}$ & $\begin{array}{l}\text { Charcoal }-\mathrm{R} \text {; black and dark } \\
\text { brown organic dotting }-\mathrm{P}\end{array}$ & $\begin{array}{l}\text { P nodules } \\
\text { and staining } \\
-\mathrm{C} \text {; root } \\
\text { bioturbation } \\
\text { - R; }\end{array}$ & $\begin{array}{l}\text { Passive layer influenced } \\
\text { by phosphatic } \\
\text { illuviation }\end{array}$ \\
\hline $\begin{array}{l}3 \\
\text { SF } 10 \\
(1 \mathrm{~cm})\end{array}$ & $\begin{array}{l}\text { Platy; pores: } \\
\text { planes; vughs, } \\
\text { chambers }\end{array}$ & $\begin{array}{l}\text { Q, Ptg, mica, moderately } \\
\text { sorted loam, preferred } \\
\text { mineral orientation; } \\
\mathrm{C} / \mathrm{F}(50 \mu \mathrm{m})=50: 50 \text {; brown, } \\
\text { crystalic Bf }\end{array}$ & $\begin{array}{l}\text { Charcoal }-\mathrm{C} \text {; articulated } \\
\text { phytoliths }-\mathrm{C} \text {; decomposed } \\
\text { organic matter }-\mathrm{C} \text {; faecal } \\
\text { spherulites }-\mathrm{R}\end{array}$ & $\begin{array}{l}\text { silty clay } \\
\text { infillings }-\mathrm{C} \text {; } \\
\text { phosphate } \\
\text { nodules }-\mathrm{C} \text {; }\end{array}$ & $\begin{array}{l}\text { Trampled and } \\
\text { maintained layer with } \\
\text { possible added straw } \\
\text { or matt }\end{array}$ \\
\hline $\begin{array}{l}3 \\
\mathrm{SF} 11 \\
1 \mathrm{~cm}\end{array}$ & $\begin{array}{l}\text { Complex; pores: } \\
\text { cracks, channels, } \\
\text { vughs, planes }\end{array}$ & $\begin{array}{l}\text { Q, Ptg, mica, well sorted, } \\
\text { no preferred mineral } \\
\text { orientation;, sorted loam; } \\
\mathrm{C} / \mathrm{F}(50 \mu \mathrm{m})=50: 50 ; \text { brown } \\
\text { to grey matrix, crystallic Bf }\end{array}$ & Black dotting $-\mathrm{P}$ & $\begin{array}{l}\mathrm{P} \text { staining }-\mathrm{C} ; \\
\mathrm{P} \text { coating }-\mathrm{P} ; \\
\mathrm{CaCO} 3 \text { nodules } \\
-\mathrm{R}\end{array}$ & $\begin{array}{l}\text { Passive layer influenced } \\
\text { by phosphatic } \\
\text { illuviation }\end{array}$ \\
\hline $\begin{array}{l}4 \\
\text { SF12 } \\
(1.5 \mathrm{~cm})\end{array}$ & $\begin{array}{l}\text { Subangular } \\
\text { blocky; pores: } \\
\text { CPV; cracks, } \\
\text { vughs }\end{array}$ & $\begin{array}{l}\text { Q, Ptg, mica, sparitic } \\
\text { carbonate, rock fragments } \\
\text { - R; no preferred mineral } \\
\text { orientation, sorted } \\
\text { homogenous loam; } \\
\mathrm{C} / \mathrm{F}(50 \mu \mathrm{m})=50: 50 \text {; light } \\
\text { brown with dark brown } \\
\text { crotovinas; crystalic Bfabric }\end{array}$ & $\begin{array}{l}\text { Charcoal - R; partly } \\
\text { decomposed OM; black } \\
\text { dotting - P; bone fragments } \\
-\mathrm{R}\end{array}$ & $\begin{array}{l}\text { Passage } \\
\text { features }-\mathrm{R}\end{array}$ & Passive layer \\
\hline $\begin{array}{l}4 \\
\text { SF13 } \\
(1 \mathrm{~cm})\end{array}$ & $\begin{array}{l}\text { Platy; pores: } \\
\text { planes }\end{array}$ & $\begin{array}{l}\text { Q, Ptg, mica, moderately } \\
\text { sorted loam, preferred } \\
\text { mineral orientation; } \\
\mathrm{C} / \mathrm{F}(50 \mu \mathrm{m})=50: 50 \text {; brown, } \\
\text { crystalic } \mathrm{Bf}\end{array}$ & $\begin{array}{l}\text { Articulated phytoliths in } \\
\text { two main layers }-\mathrm{C} \text {; bones } \\
\text { - C; burned bones }-\mathrm{R} \text {; } \\
\text { decomposed OM - C, partly } \\
\text { decomposed OM - P; egg } \\
\text { shell - R; charcoal - P, }\end{array}$ & $P$ coating $-P$ & $\begin{array}{l}\text { Trampled and } \\
\text { maintained layer with } \\
\text { possible matting }\end{array}$ \\
\hline $\begin{array}{l}4 \\
\text { SF } 14 \\
(2 \mathrm{~cm})\end{array}$ & $\begin{array}{l}\text { Subangular } \\
\text { blocky; pores: } \\
\text { CPV; cracks, } \\
\text { vughs }\end{array}$ & $\begin{array}{l}\text { Q, Ptg, mica, sparitic } \\
\text { carbonate, rock fragments } \\
-\mathrm{R} \text {; no preferred mineral } \\
\text { orientation, sorted } \\
\text { homogenous loam; } \\
\mathrm{C} / \mathrm{F}(50 \mu \mathrm{m})=50: 50 ; \text { light } \\
\text { brown; crystalic Bfabric }\end{array}$ & $\begin{array}{l}\text { Charcoal - R; partly } \\
\text { decomposed OM; black } \\
\text { dotting - P; }\end{array}$ & $\begin{array}{l}\text { Passage } \\
\text { features }-\mathrm{R} \text {; } \\
\mathrm{P} \text { nodules and } \\
\text { staining }-\mathrm{P} \text {, } \\
\text { channels }-\mathrm{R} \text {; } \\
\text { CaCO3 nodules } \\
-\mathrm{P}\end{array}$ & $\begin{array}{l}\text { Passive layer } \\
\text { postdepositionally } \\
\text { influenced by p } \\
\text { iluviation }\end{array}$ \\
\hline
\end{tabular}




\section{Results}

\subsection{Sedimentological and geochronological context}

Sample 1 was macroscopically composed of two strata (209 and 211) (Figure 2). The lower layer (209) was composed of plastic yellow loam. The original thickness of this layer was 2-8 $\mathrm{cm}$. The overlying layer marked as 211 was composed of light grey plastic loam with visible microlayering. The construction features of the building were rarely preserved and they are represented by column and post pits sunken into the floor. The floor plan was probably $7 \times 5$ metres in size and the building was situated at the edge of the NW part of the plot. A fireplace, heating facility or another function feature was not identified. Stratigraphically, the building reflects one of the oldest activities at the plot - dated to the $13^{\text {th }}$ century. The abandonment of the building was not triggered by fire. The absence of daub suggests the wooden construction of the building. After abandonment, the site was used as a garbage dump area. A new building constructed there later is represented by sample 2 .

Sample 2 was macroscopically composed of one layer of ochre-coloured plastic loam (Figure 2). In some parts microlamination was detected. The thickness of this layer was approximately $25 \mathrm{~cm}$. The floor plan was approximately
8.0 $\times 7.5$ metres in size. Construction features were not identified. In the NE part of the building repaired relicts of the heating facilities were detected. Its relationship to the excavated building remained unclear. The building was abandoned after a fire, which was documented by the charcoal layer and burned daub. It is possible to date the building to the younger period (from the second half of the $13^{\text {th }}$ century to the first half of the $14^{\text {th }}$ century).

Sample 3 was macroscopically described as being composed of three layers (Figure 3). The lowermost layer was composed of ochre plastic loam 2-10 cm thick (marked as 2149). The layer above (marked as 2150) was composed of brown-grey plastic loam and its thickness was approximately 1-2 cm. The layer marked as 2142 overlapping this stratum had a similar character to that of layer 2149. The thickness of the 2142 layer was approximately $6-5 \mathrm{~cm}$. The building was only detected due to the presence of the brown-grey trampled layer (layer 2150), but its type of construction and form remained unclear. Its floor plan was probably rectangular with the width exceeding 4.5 metres (perhaps up to 6-7 metres) and length of 6 metres. This feature was located near the southern part of the plot at a distance of approximately 20-26 metres from the street. A function

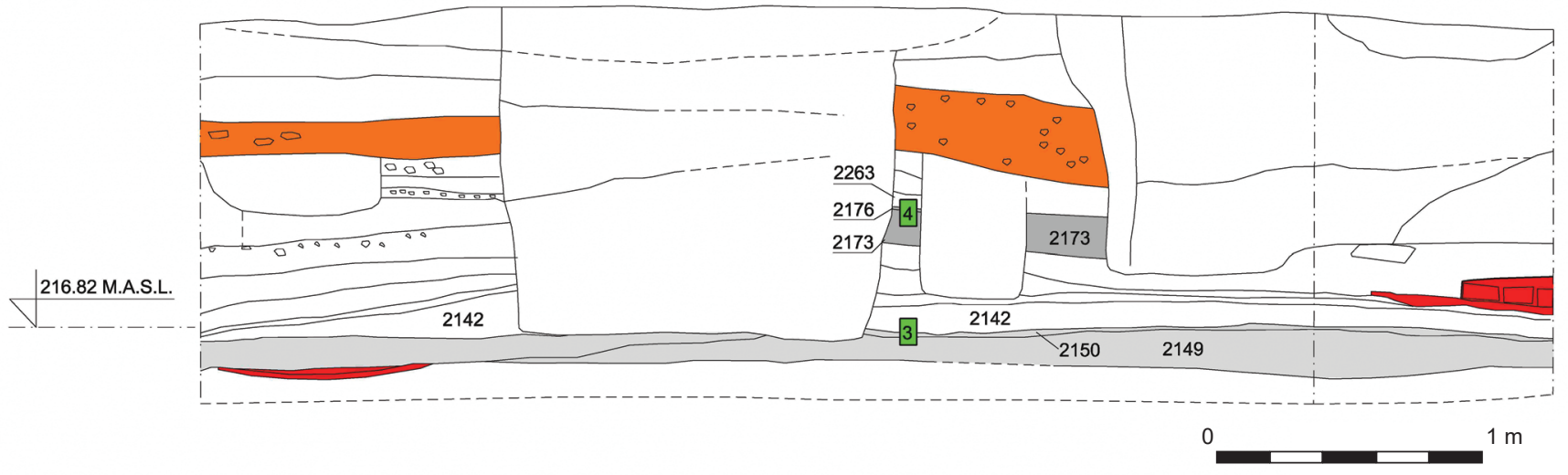

Figure 2. The documentation of studied deposits of the first and second building.

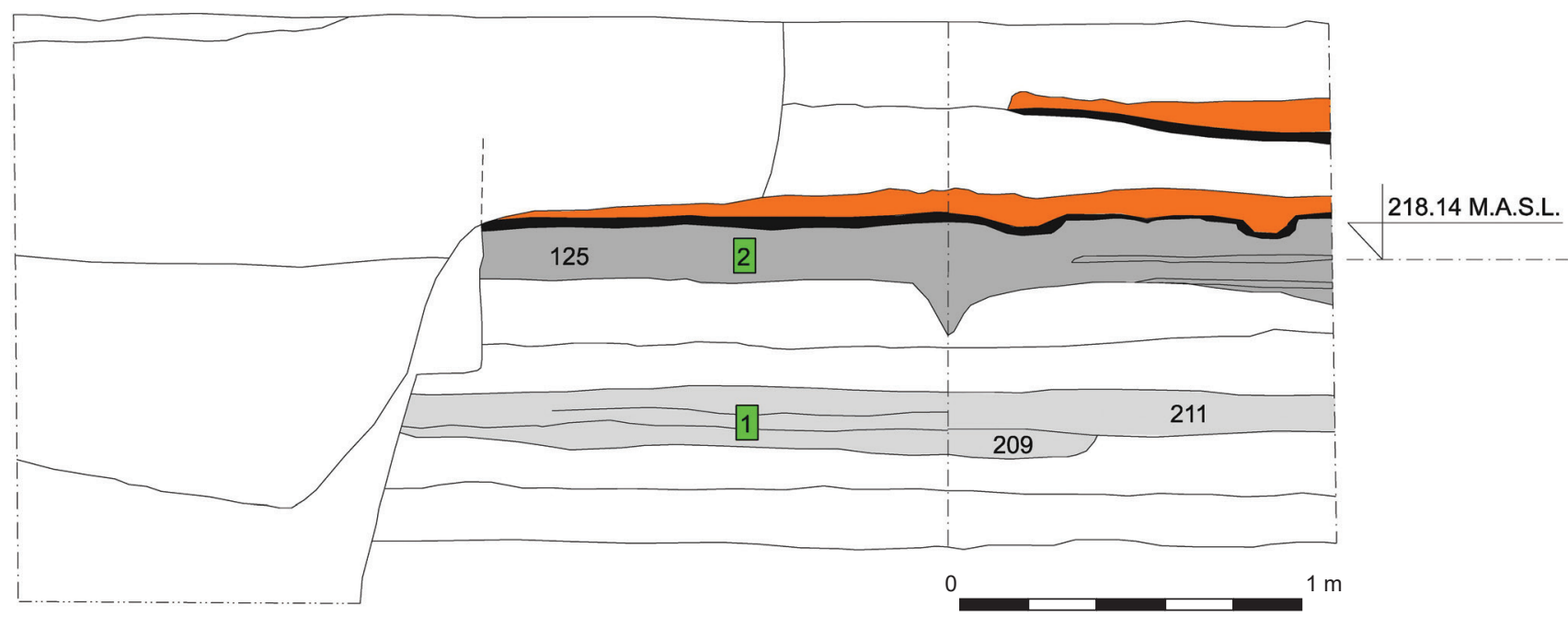

Figure 3. The documentation of studied deposits of the third and fourth building. 
of this feature was not identified. A relict of a non-specific heating facility was recorded there. A $13^{\text {th }}$ century antiquity of the feature was suggested based on diagnostic features of its ceramic fragments. It appears that layer 2142 is, in fact, a new floor horizon of the same building. The long-term activities in the same area are captured in sample 4 .

Sample 4 was macroscopically composed of three layers. The lowermost layer was composed of ochre plastic loam 12-24 cm thick (marked as 2173). The overlying layer 2176 was $0.5-1 \mathrm{~cm}$ thick and it was composed of browngrey plastic loam. It was overlain by layer 2263 with a similar appearance to layer 2173. Layer 2263 was $10 \mathrm{~cm}$ thick. The function of this feature was not identified and the structure and floor plan of this building remained unclear. It is probable that the floor plan had a width of 4 metres and length greater than 2 metres. The described strata are in fact the second stage of the building from where sample 3 was taken, and it is clear that the building had become smaller and also shifted towards the street line. The dimension of the younger building decreased and the backyard of the building became an open space. It also means that the back of the building was located only 23 metres from the street line during the existence of the younger building. The open space is documented by the pavement constructed of stone layers (thickness of $0.4 \mathrm{~m}$ ). Based on a ceramic fragment, the age of the feature was estimated from the later part of the $13^{\text {th }}$ century up to the first half of the $14^{\text {th }}$ century. The occupation ended after the building was destroyed in a fire.

\subsection{Micromorphological description of studied strata}

Micromorphological observations usually reveal much greater detail of subfacial variability. Sample 1 was divided into 5 subfacies (Figure 4) and the transition between macroscopically-divided layers is therefore not so simple to explain. It is possible that subfacies $1-4$ corresponds to layer 211, while subfacies 5 corresponds to layer 209. The mineral compositions are quite similar. Generally, subfacies 1 and 5 are the most similar to each other. They are both composed of soil aggregates and unsorted with a subangular, blocky microstructure. The main difference between these two subfacies is the presence of recently-formed gypsum crystals and phosphatic nodules found in subfacies 1 . Subfacies 2 is sorted, quite homogenous with the occasional presence of charcoal, phytoliths, gypsum crystals and with a visible orientation of the mineral fraction. A similar orientation is also visible in subfacies 3 , but the composition of this subfacies is quite distinct: articulated phytoliths and microcharcoal are quite common. The surface is slightly undulated. Subfacies 4 is quite homogenous, sorted, with rare organic matter and gypsum crystals. It has a platy microstructure and it is fully impregnated by phosphates (Table 1)

While, on the one hand, only one layer, albeit with slight microlayering, was identified macroscopically in sample 2 (Figure 5), micromorphological observations revealed that at least three layers are present. The uppermost part of the sample (labelled subfacies 6) is represented by a sorted loam of a loess origin with a minimal amount of organic material. Mineral orientation was not detected here. The layer below (marked as subfacies 7) is quite different. It contains a lot of chambers and cracks, organic matter, bone fragments, phosphate nodules, and recently-formed gypsum crystals. The third-described subfacies (SF 8) is relatively homogenous with a small amount of organic material, moderately-sorted, sandy loam with an increased amount of mica (in contrast to subfacies 6). This may indicate a different provenance of its source material. A detailed description is provided in Table 1.

Sample 3 contained three subfacies (Figure 6), which can be linked to the original macroscopic description. The
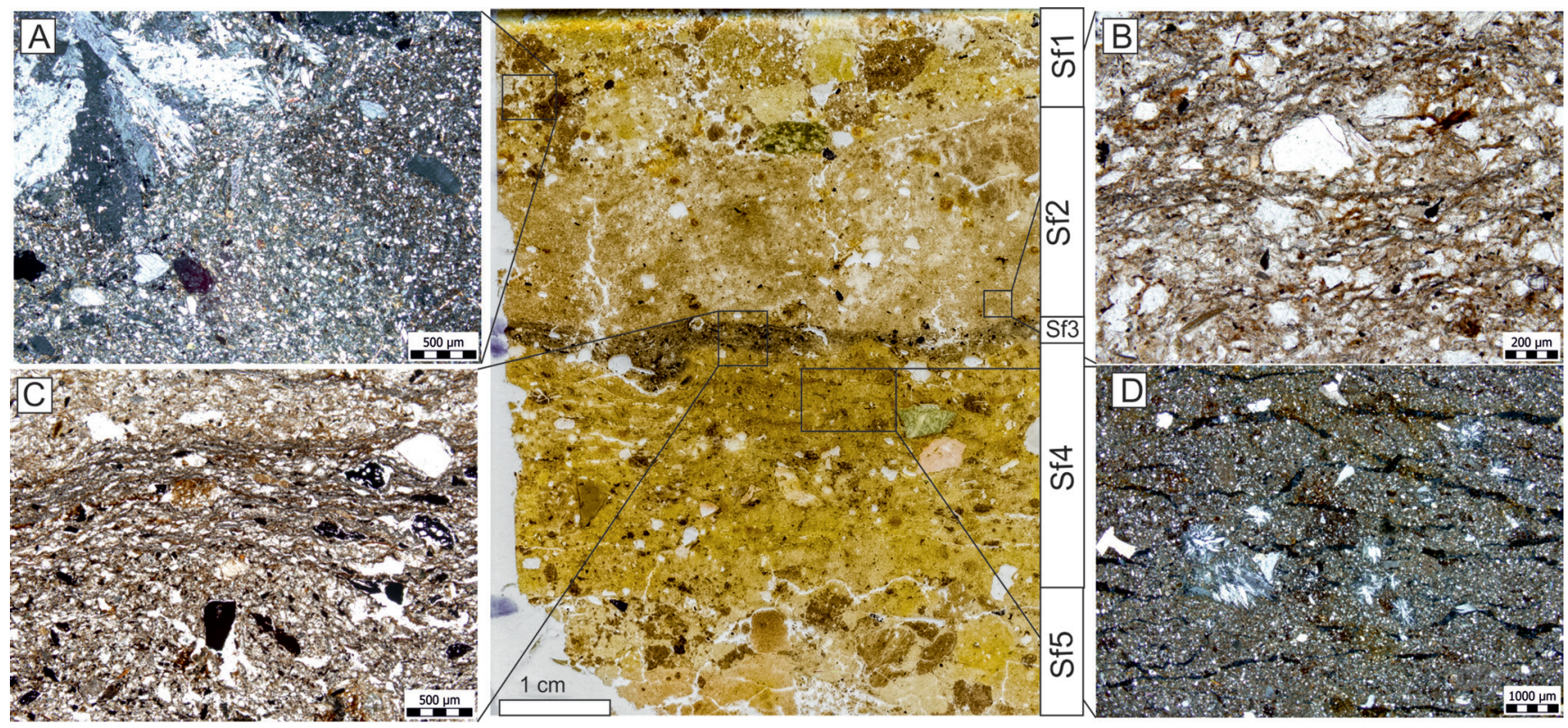

Figure 4. Sample 1 and divided subfacies. 

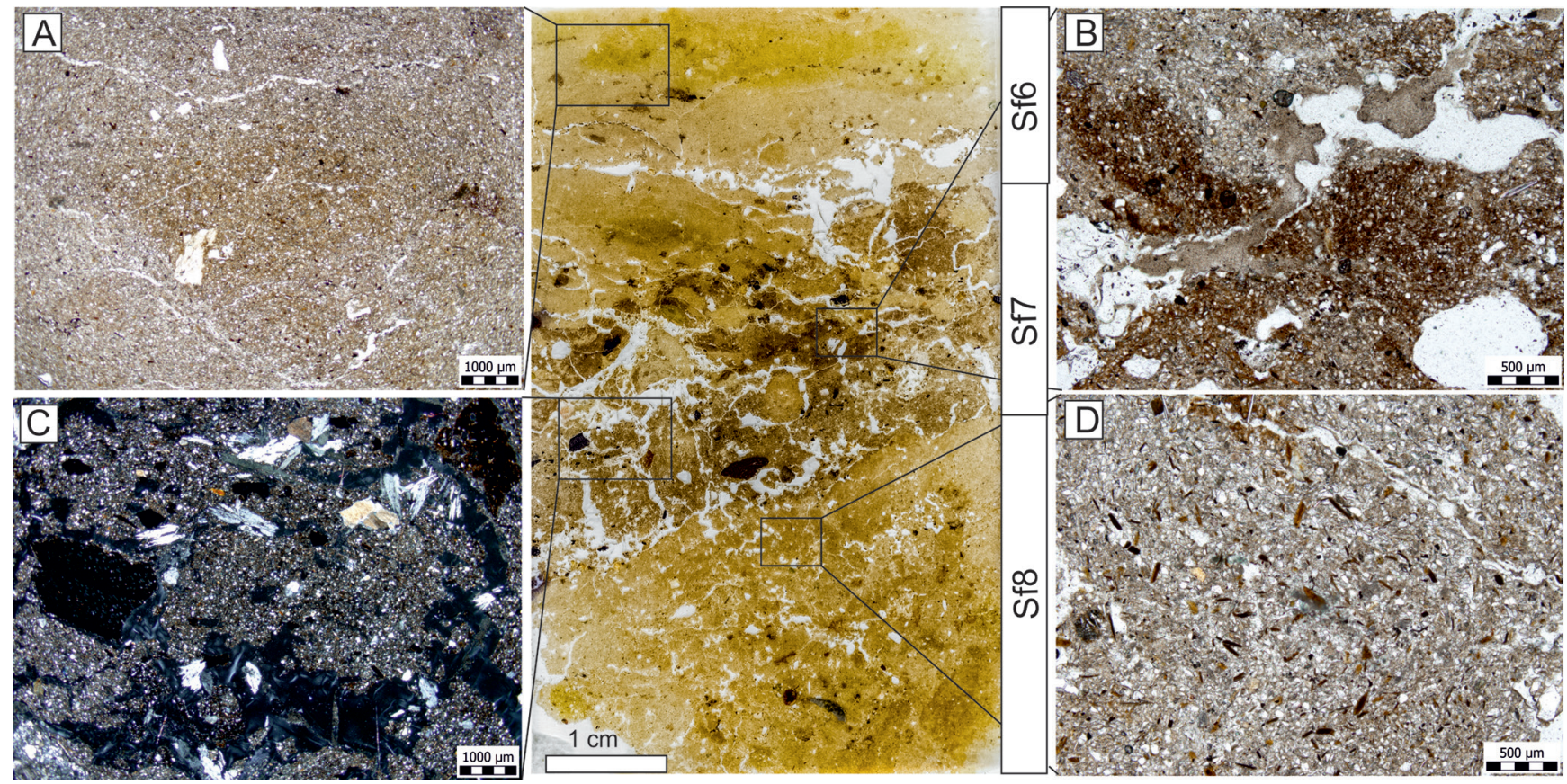

Figure 5. Sample 2 and divided subfacies.
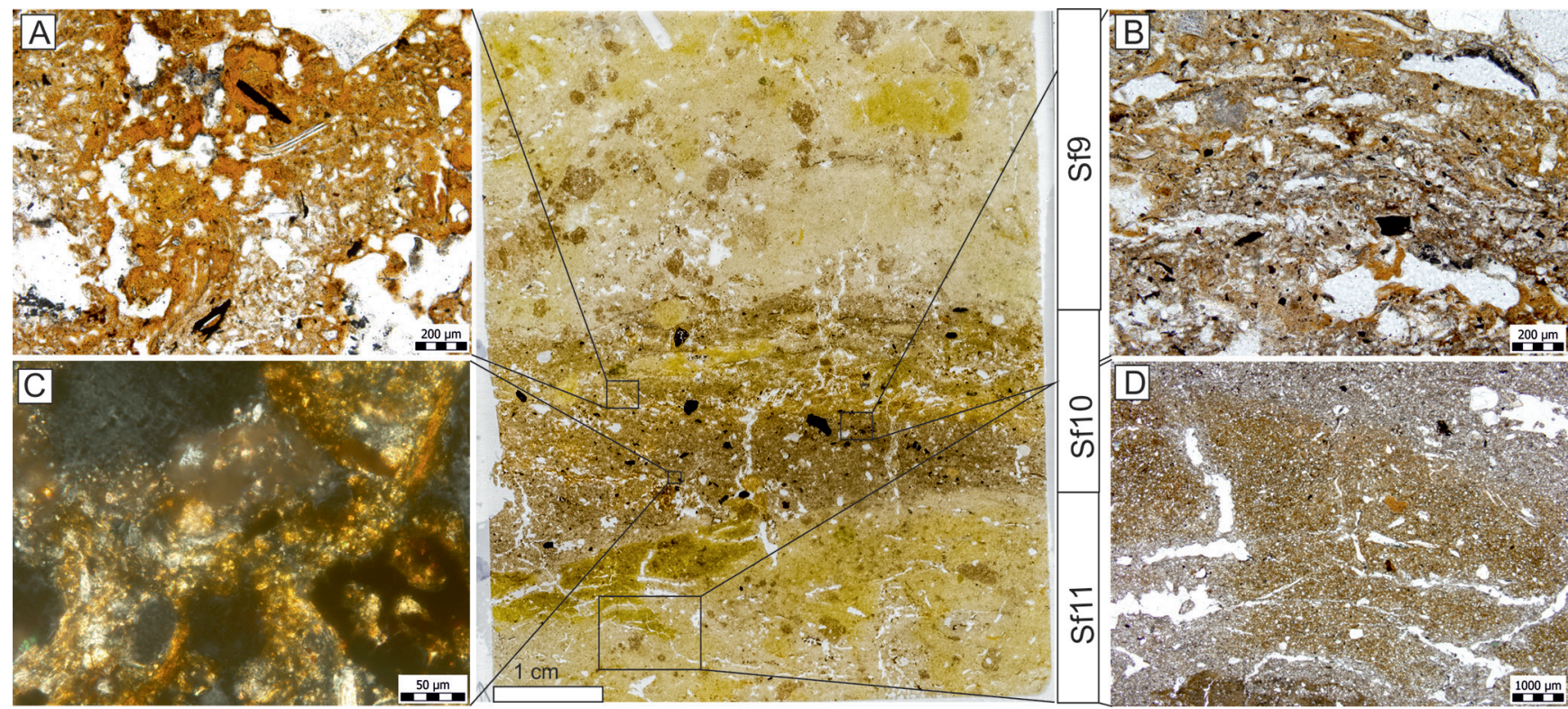

Figure 6. Sample 3 and divided subfacies.

subfacies marked as SF9 therefore corresponds to layer 2142, subfacies marked as SF10 corresponds to layer 2150 , and subfacies marked as SF11 corresponds to layer 2149. As already visible during the macroscopic observations, subfacies SF9 and SF11 are quite similar, composed of sorted loam with a minimal amount of organic residue. The main difference is the presence of crotovinas in subfacies SF9. Subfacies SF 10 represents the surface where different organic residues have accumulated over time. The presence of articulated phytoliths and the presence of silty-clay infillings and phosphate-rich accumulations is significant. This is the only case where occasional faecal spherulites were detected (see details in Table 1).
Sample 4 (Figure 7) is quite similar to sample 3. In sample 3, the micromorphogically-divided subfacies also corresponded to the macroscopical observations. Subfacies SF12 corresponds to layer 2263, subfacies SF13 corresponds with layer 2176, and SF14 corresponds with layer 2173. While SF12 and SF14 are quite sterile, homogenous loams (with SF14 more post-depositionally influenced by illuviated $P$ than SF12), layer SF13 represents the surface where different organic residues have accumulated (in a similar fashion to SF 10). In this case, very abundant articulated phytoliths are apparent in the two layers interrupted by a thin layer of a matrix similar to SF12 and SF14; bone fragments, burned bone fragments, charcoal and decomposed organic 

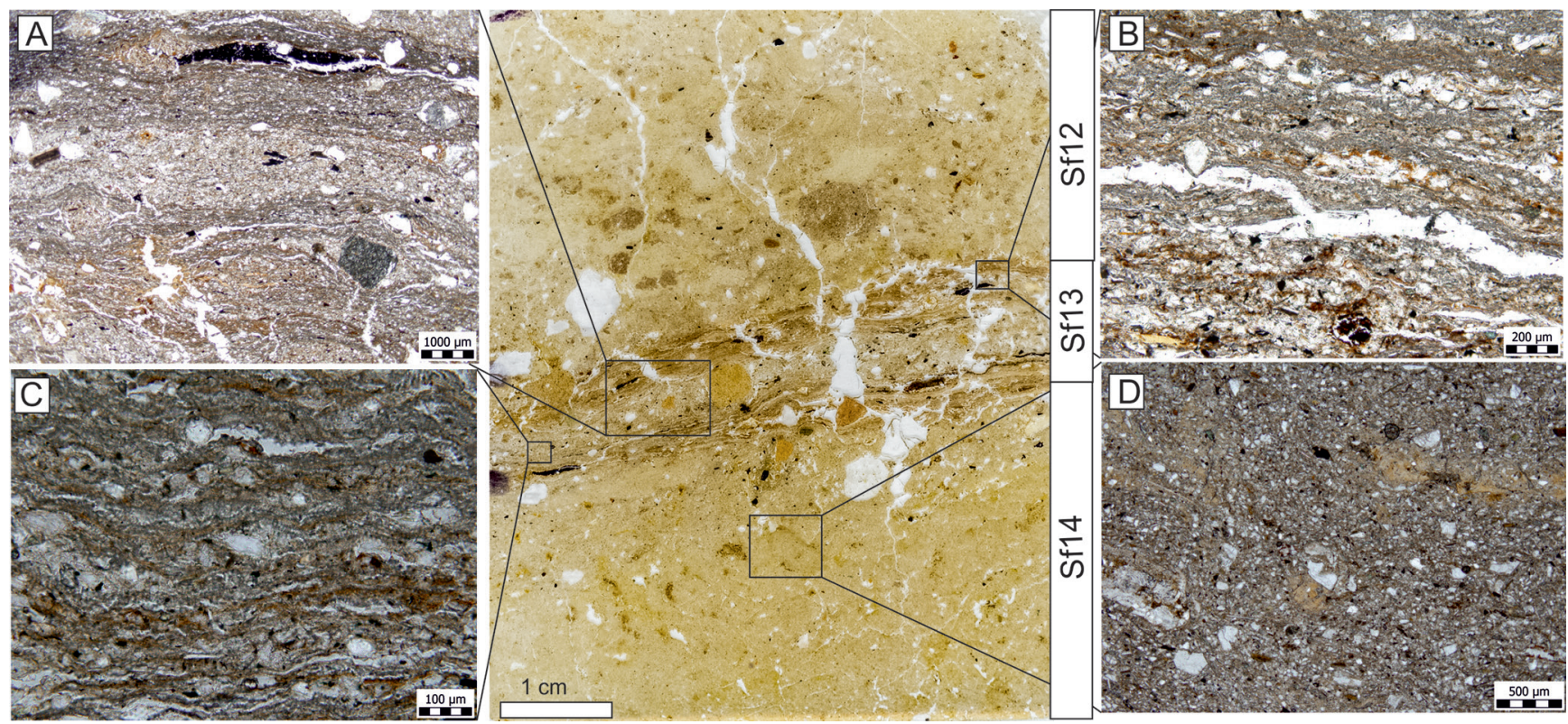

Figure 7. Sample 4 and divided subfacies.

matter were all frequently present. In contrast to SF10, however, the silty-clay infillings were not observed here (see details in Table 1).

\section{Discussion}

\subsection{The role of preparation layers}

The micromorphological observations of the presented samples revealed quite distinct differences between the "floors" observed macroscopically. There is the everpresent question of what exactly should be called a "floor" - it is not merely the surface where accumulation of occupational debris, trampling and maintenance take place (see details in Macphail and Goldberg, 2018). As already stated, the "floor" is usually quite a complex term subsuming the preparation (passive) layer and trampled/ dumped/maintained (active) layer (see review in Karkanas and Goldberg, 2019; Macphail and Goldberg, 2018). At the very minimum, buildings $1,2,3$ and 4 contained intentionally-prepared, passive layers (SF5 for building 1, SF8 for building 2, SF11 for building 3 and SF14 for building 4 - see Table 1). In building 1, the passive layer (SF5) represents a deterioration from older daub. This was an unexpected finding, because archaeologists did not recover any evidence of older construction activities in building 1. One possibility is that the passive layer was intentionally prepared using a loam daub from older destroyed structures. Such material is very difficult to recognize by common archaeological techniques if it has not been influenced by fire destruction.

The passive layer of building 1 (SF5) and the overlying building 2 (SF8) differ in their provenance. While building 1 possesses a passive layer composed of soil and loess aggregates (SF5), building 2 has a passive layer consisting of silty loam that originated from river alluvium (SF8). There could be many reasons for the decision to use a different material, ranging from better permeability (see Lisá et al., 2009) to easier access to the source material.

In the case of buildings 3 and 4, the passive layer was composed of sorted loam represented by redeposited loess (SF11 and SF14).

Another layer, which, in some cases, may also be understood as the passive layer, is the material above the active layer (see SF1 for building 1, SF6 for building 2, SF9 for building 3 and SF12 for building 4). In the case of building 1 (SF1), it is composed of construction material which corresponds with the macroscopical observations, i.e. the building was not destroyed by fire. On the other hand, we know that the second building was destroyed by fire, but the layer situated above the active layer (SF6) is not composed of burned daub or charred material. Could this mean that subfacies SF 1 (composed of unburned daub remains) represents another passive layer? In such a case we would need to assume that building 2 had two phases of floor preparation (SF8 and SF6), and that we were not able to detect the second active layer macroscopically buried under the fire debris.

Buildings 3 and 4 have similar passive layers (SF11 and SF14). In both cases, these are represented by homogenous loam with a probable loess origin. These sediments are not in fact contaminated by daub or burned daub and were used as intentionally-prepared passive layers. Again, this suggests that for buildings 3 and 4 the active layers had to be repaired by the intentional accumulation of a new passive layer (in the case of building 3 it should be SF9, and for building 4 it should be SF12). This also means that we were not able to discern the second active layers of these buildings, probably because they were buried and destroyed under the final debris. 


\subsection{The information value of the active layer}

The active layers provided interesting information about the use of the buildings: It was not clear during the archaeological excavations if we were dealing with a house, byre or a stable (see review in Macphail and Goldberg, 2018). All studied samples showed that the active layers should most probably be linked most probably with domestic floors. One of the main reasons for this assertion is that the studied active floors do not contain fragments of animal dung (Shahack-Gross, 2017; Canti and Brochier, 2017). The only case where a rare presence of faecal spherulites was detected is the active layer of building 3 (SF10). We had an opportunity to see how the active floor layer changes over time in the same position at a single plot.

In the case of building 1 (SF2 and 3) and building 2 (SF7) the change was quite dramatic and probably corresponds with a change in the cultural-behavioural status of the building. The active layer of the older building (SF2 and 3) shows signs of repeated maintenance. It seems that two phases of digging maintenance were detected. Maintenance of the older one (detected in SF3 - see Table 1) included mainly wet sweeping and adding straw to the floor; continuous trampling and sweeping accumulated at least a $1 \mathrm{~cm}$ thick layer. This may correspond to one generation (Lisá et al., forthcoming). The overlying layer (SF2 - see Table 1) shows a slightly different type of maintenance. At first, the floor was probably maintained by wet sweeping. The wetting triggered illuviation of phosphates down the section and its drying out produced the more-recently-formed gypsum crystals. The absence of vivianite reflects the absence of redoximorphic conditions. The thickness of the active layer is again approximately $1 \mathrm{~cm}$, which may correspond to another single generation (occupation) of the building. Extended beating of the surface corresponding with longterm use is represented by the planes imprinted in the layer below the active layers, i.e. in SF4.

Building number 2 has a different active layer. The high porosity of the active layer combined with the missing planes, a number of wood fragments, bone and organic dumping suggests its origin under a planked floor. The plank floor was probably maintained by wet sweeping, which produces the silty-clay coating within the active layer (SF7). The use of the plank floor does not necessarily indicate a change of building use - to an elevated cultural-behavioural status. We do not yet know what was the surface difference between different parts of the building, but we can assert that the active floor layer differed between building 1 and building 2 .

Significant differences are also present between the active floor layers of buildings 3 and 4 . Furthermore, the active floors detected in buildings 3 and 4 (SF10 and 13) significantly differ to the active floors detected in buildings 1 and 2 (SF2, 3 and 7). In both cases, the active layers of buildings 3 and 4 (SF10 and 13) are composed of articulated phytoliths. In the older building (building 3, SF10), the active layer is extremely rich in phosphates, and the presence of articulated phytoliths is not as significant as in the active layer of building 4 . One possible explanation is the presence of cover mats on the surface. Organic mats laid on the surface may prevent the mechanical influence of a floor surface and the initiation of muddy surfaces, and thus make the surface drier. Two thick mats, or two phases of mat accumulation, were certainly detected in building 4 . It seems that in both cases, the surface of the mats was maintained by sweeping because the inorganic material within the floor is oriented horizontally. The idea of the presence of organic mats may also suggest that the surface in plot 2 (buildings 3 and 4) was probably much wetter than in buildings 1 and 2 . The layers (expressed in SF11 and SF14) situated below these active layers have signs of phosphate illuviation but no signs of recent gypsum, so the question is if the maintenance was due to wet sweeping. In every case, the use of space in buildings 3 and 4 did not differ much over time, but it did differ significantly between buildings 1 and 2 .

\section{Conclusions}

Micromorphological analyses of floors from the four buildings excavated within one plot revealed new information about the use of domestic floors in space and over time. In the case of buildings 1 and 2, which are situated in superposition, the type of active floor did change significantly, which suggests a change in cultural habits, or the status of the building (room). During the older phase ( $13^{\text {th }}$ century), the surface of the active floor layer was swept, and then wet swept and kept clean. During the younger phase represented by building 2 (from end of the $13^{\text {th }}$ century to the beginning of the $14^{\text {th }}$ century), the building may have had a plank floor which was maintained by wet sweeping.

In the case of buildings 3 and 4 , also situated in superposition, the type of active floor did not noticeably change over time. During the $13^{\text {th }}$ century (building 3 ), the end of the $13^{\text {th }}$ century and the beginning of the $14^{\text {th }}$ century, the surface of the active floor layer was covered repeatedly by hay, straw or by mat coverings (especially in building 4 ) and kept clean by sweeping. The surface was much wetter than in buildings 1 and 2, which may be related to the different periods of building construction. At the same time, it can be stated that the position of the buildings within the plot determined the way the buildings were used. The exact use of the buildings has not so far been determined, but it is possible that buildings 3 and 4 possessed a lower social status than buildings 1 and 2 .

The structures of the passive layers show that they were mostly intentionally prepared and the material used for the preparation differed based on unknown conditions. In some cases, pure loess was used while in other cases, older debris, or alluvial river deposits, were used for construction of the passive layer.

\section{Acknowledgements}

The research was financed by GA CR project No. 17$23836 \mathrm{~S}$ - Transformation of the Burgher House in the $13^{\text {th }}$ 
century (Brno-Prague-Wroclaw) - and co-financed by the internal programme of the Institute of Geology of the Czech Academy of Sciences, v. v. i., in Prague No. RVO 67985831. The authors would like to thank both anonymous reviewers, who helped to increase the quality of this paper.

\section{References}

BANERJEA, R.Y., BELL, M.G., MATTHEWS, W., BROWN, A.D., 2015a Applications of micromorphology to understanding activity areas and site formation processes in experimental hut floors. Archaeological and Anthropological Sciences, 7(1), 89-112.

BANERJEA, R.Y., FULFORD, M., BELL, M., CLARKE, A., MATHEWS, W., 2015b. Using experimental archaeology and micromorphology to reconstruct timber-framed buildings from Roman Silchester: a new approach. Antiquity, 89(347), 1174-1188.

BORDERIE, Q., BALL, T.B., BANERJEA, R.Y., BIZRI, M., LEJAULT, C., SAVE, S., VAUGHAN-WILLIAMS, A., 2018. Early Middle Ages houses of Gien (France) from the inside: geoarchaeology and archaeobotany of $9^{\text {th }}-11^{\text {th }}$ c. floors. Environmental Archaeology, 2018, 1-19.

CANTI, M.G., BROCHIER, J.E., 2017. Faecal Spherulites. In: C. Nicosia, G. Stoops, eds. Archaeological Soil and Sediment Micromorphology. Oxford: Wiley Blackwell, pp. 51-54.

COURTY, M.A., GOLDBERG, P., MACPHAIL, R.I., 1989. Soils and Micromorphology in Archaeology. Cambridge Manuals in Archaeology. Cambridge: Cambridge University Press.

HOLUB, P., KOLǍ̌ÍK, V., MERTA, D., PEŠKA, M., ZAPETALOVÁ, D., ZŮBEK, A., 2005. Ke stavu poznání nezděné měšt'anské architektury vrcholně středověkého Brna. Forum urbes medii aevi, 2, 44-101.

HOLUB, P., KOLAŘÍK, V., MERTA, D., PEŠKA, M., ZŮBEK, A., 2013. Bürgerliche Architektur des hochmittelalterlichen Brno/ Brünn. In: Y. Hoffmann, U. Richter, eds. Die Frügeschichte Freibergs im überregionalen Vergleich. Städtische Frügeschichte - Bergbau - früher Hausbau. Halle, pp. 457-471.

HOLUB, P., KOLAŘÍK, V., MERTA, D., PEŠKA, M., ZŮBEK, A., 2015. Medieval Brick Architecture in Brno in the Context of South Moravia. Forum urbes medii aevi, 9(1-2), 310-337.

KARKANAS, P., GOLDBERG, P., 2019. Reconstructing Archaeological Sites; Understanding the Geoarchaeological Matrix. Oxford: Wiley Blackwell.

KUNA, M., HAJNALOVÁ, M., KOVAČIKOVÁ, L., LISÁ, L., NOVÁK, J., BURES̆, M., CÍLEK, V., HOŠEK, J., KOČÁR, P., MAIER, A., MAKOWIECKI, D., SCOTT CUMMINGS, L., SƯVOVÁ, Z., SVĚTLÍK, I., VANDENBERGHE, D., VAN NIEULAND, J., YOST, C., ZABILSKA-KUNEK, M., 2013. Raně středověký areál v Roztokách z pohledu ekofaktů. Památky archeologické, 104, 59-147.

LISÁ, L., KOČÁR, P., BAJER, A., KOČÁROVÁ, R., SYROVÁ, Z., SYROVÝ J., PORUBČANOVÁ, M., LISÝ, P., PEŠKA, M., in print. The Floor - a voice of human lifeways. A geo-ethnographical study of historical and recent floors at Dolní Němčí Mill, Czech Republic. Archaeological and Anthropological Sciences.
LISÁ, L., KOLǍ̌ÍK, V., BAJER, A., 2009. The geoarchaeological and micromorphological reconstruction of medieval food store room floor layers; the case study from Tišnov, Czech Republic. Frankfurter Geowissenschaftliche Arbeiten. Serie D, Band 30, Archaeological Soil Micromorphology, 71-80.

MACPHAIL, R.I., CRUISE, G.M., ALLEN, M.J, LINDERHOLM, J., REYNOLDS, P., 2004. Archaeological soil and pollen analysis of experimental floor deposits; with special reference to Butser Ancient Farm, Hampshre, UK. Journal of Archaeological Science, 31, 175-191.

MACPHAIL, R.I., CROWTHER, J., CRUISE, G.M., 2007. Microstratigraphy: soil micromorphology, chemistry and pollen, In: D. Bowsher, T. Dyson, N. Holder, I. Howell, eds. The London Guildhall. An archaeological history of a neighbourhood from early medieval to modern times. MoLAS Monograph 36, London: Museum of London Archaeological Service.

MACPHAIL, R.I., CROWTHER, J., CRUISE, G.M., 2007. Micromorphology and post-Roman town research: the examples of London and Magdeburg. In: J. Henning, ed. Post-Roman Towns and Trade in Europe, Byzantium and the Near-East. New methods of structural, comparative and scientific methods in archaeology. Berlin: Walter de Gruyter \& Co. KG, pp. 303-317.

MACPHAIL, R.I., GOLDBERG, P., 2018. Applied Soils and Micromorphology in Archaeology. Cambridge: Cambridge University Press.

MILEK, K., 2012. Floor formation processes and the interpretation of activity areas: an ethnoarchaeological study of turf buildings at Thvera, northeast Iceland. Anthropological Archaeology, 31, 119-137.

NICOSIA, C., STOOPS, G., 2017. Archaeological Soil and Sediment Micromorphology. Oxford: Wiley Blackwell.

NOVÁK, J., LISÁ, L., POKORNÝ, P., KUNA, M., 2012. Charcoal analyses as an environmental tool for the study of Early Medieval sunken houses infills in Roztoky near Prague, Czech Republic. Journal of Archaeological Science, 39(4), 808-817.

PARMA, D., LISÁ, L., JAROŠOVÁ, M., PETR, L., 2011. Geoarchaeology of La Tène Sunken Houses at Syrovice, Czech Republic: Importance for Understanding Living Strategies. Interdisciplinaria Archaeologica, Natural Sciences in Archaeology, 2(1), 15-25.

PŘICHYSTAL, A., 2011. Geologie brněnského prostoru. In: R. Procházka, ed. Dějiny Brna 1. Od pravěku k ranému středověku. $1^{\text {st }}$ ed., Brno: Statutární město Brno, Archiv města Brna, pp. 17-40.

RENTZEL, P., NICOSIA, C., GEBHARDT, A., BRÖNNIMANN, D., PÜMPIN, C., ISMAIL-MEYER, K., 2017. Trampling, poaching and the effects of traffic. In: C. Nicosia, G. Stoops, eds. Archaeological Soil and Sediment Micromorphology. Chichester: Wiley Blackwell, pp. 281-298.

SHAHACK-GROSS, R., 2017. Animal Gathering Enclosures. In: C. Nicosia, G. Stoops, eds. Archaeological Soil and Sediment Micromorphology. Chichester: Wiley Blackwell, pp. 265-280.

STOOPS, G., 2003. Guidelines for Analysis and Description of Soil and Regolith Thin Sections. Madison, Wisconsin, USA: Soil Science Society of America.

STOOPS, G., MARCELINO, V., MEES, F., 2010. Interpretation of Micromorphological Features of Soils and Regoliths. Amsterodam: Elsevier.

VIČAR, O., 1965. Místopis Brna v polovici 14. století. Prostor uvnitř městských hradeb. Brno v minulosti a dnes, 7, 242-283. 